\title{
ANALISIS KELAYAKAN ISI MATERI DARI KOMPONEN MATERI PENDUKUNG PEMBELAJARAN DALAM BUKU TEKS MATA PELAJARAN SOSIOLOGI KELAS XI SMA NEGERI DI KOTA BANDUNG
}

\author{
Lutfia Putri Kinanti, Sudirman \\ Universitas Pendidikan Indonesia \\ Jl. Dr.Setiabudi 229 Bandung 40154, Jawa Barat, Indonesia \\ Email:fykinanti09@gmail.com
}

\begin{abstract}
Abstrak Kelayakan isi materi merupakan satu di antara empat kriteria penilaian kelayakan buku teks yang harus diperhatikan dan disesuaikan dengan peraturan yang telah ditetapakan oleh Badan Standar Nasional Pendidikan (BSNP). Buku teks menjadi sumber utama dalam proses belajar mengajar dan dijadikan acuan untuk mencari informasi dan penunjang kegiatan pembelajaran oleh guru maupun peserta didik. Permasalahan yang dirasakan terdapat pembahasan dalam materi yang kurang mendalam dan konten yang kurang memadai dalam buku teks tersebut. Tujuan dari penelitian ini adalah untuk mengetahui lebih spesifik tingkat kelayakan buku teks yang akan dinilai yaitu untuk mengetahui tingkat kelayakan buku teks ditinjau dari kesesuaian uraian materi dengan Kompetensi Inti (KI) dan Kompetensi Dasar (KD) pada buku teks sosiologi, tingkat keakuratan materi, dan materi pendukung pembelajaran. Penelitian ini menggunakan pendekatan kualitatif dengan metode deskriptif. Pengumpulan data pada penelitian ini menggunakan teknik observasi, wawancara, studi dokumentasi dan studi literatur. Teknik analisis datanya menggunakan teknik analisis konten, di mana peneliti melakukan analisis terhadap buku yang dikaji. Hasil penelitian menunjukkan bahwa tingkat kesesuaian dengan Komptensi Inti (KI) dan Kompetensi Dasar (KD) cukup layak karena kurang ditekankan aspek KI 1 dan KI 2. Keakuratan materi layak, hal ini menunjukkan secara keseluruhan materi yang tersaji sudah akurat hanya saja tidak setiap pembahasan dapat menampilkan teori. Materi pendukung pembelajaran berada pada status layak akan tetapi terdapat catatan karena kurang menekankan pada aspek teknologi, contoh dan gambar kurang memadai, tampilan yang kurang full colour dan terdapat beberapa soal yang kurang sinkron.

Kata kunci: $\quad$ buku teks, kelayakan isi materi, sosiologi
\end{abstract}

\section{PENDAHULUAN}

Pendidikan merupakan salah satu bentuk perwujudan kebudayaan manusia yang dinamis. Karena itu, perubahan dalam bidang pendidikan adalah hal yang memang seharusnya terjadi sejalan dengan perubahan budaya kehidupan. Misi dunia pendidikan adalah melahirkan generasi-generasi penerus yang memiliki intelektualitas tinggi serta menciptakan peradaban yang berkarakter kuat. Hasil ini tertuang dalam bunyi pasal 3 Undang-Undang No. 20 Tahun 2003 tentang Sistem Pendidikan Nasional. Namun untuk penyelenggaraan pendidikan dalam mencapai tujuan tersebut diperlukan kurikulum.

Menurut Nasution (2008, hlm. 5) "Kurikulum adalah suatu rencana yang disusun untuk melancarkan proses belajar mengajar dibawah bimbingan dan tanggung jawab sekolah atau lembaga pendidikan beserta stafnya". Kurikulum dijadikan pedoman untuk terlaksananya proses pembelajaran yang terarah, sistematis, dimana di dalam kurikulum tersebut terdapat komponenkomponen yang mempengaruhi penulisan buku teks buku teks. Menurut Safdar (dalam International Journal of Academy Research, 2011, hlm. 45) bahwa "buku teks adalah dasar dan pelengkap pembelajaran guru dalam proses belajar mengajar. Buku teks menjadi dasar dan pendukung pada aktivitas pembelajaran di kelas". Dengan begitu buku yang digunakan baik untuk peserta didik maupun guru harus jelas baik itu berkaitan dengan informasi, konsep dan mengembangkan kemampuan sehingga dapat dipahami oleh peserta didik dalam menguasai kompetensi tertentu dan menunjnag aktivitas pembelajaran di kelas. 
Berdasarkan data yang didapat dari hasil observasi buku teks yang dijadikan subyek penelitian adalah buku teks yang pada umumnya dijadikan referensi dan acuan dalam pembelajaran. Adapun buku tersebut adalah buku teks Esis. Dari 29 SMA Negeri di Kota Bandung, 13 diantaranya menggunakan buku teks esis dalam proses belajarmengajar.

Dalam penilaian kelayakan isi terdapat 4 indikator penilaian sesuai dengan yang sudah ditetapkan oleh Badan Standar Nasional Pendidikan (BSNP). Adapun keempat indikator tersebut adalah kelayakan isi, kelayakan penyajian, kelayakan kebahasaan dan kelayakan kegrafikan. Dalam pembahasan kali ini fokus kepada kelayakan isi, untuk kelayakan isi terdiri dari 3 komponen yaitu kesesuaian dengan $\mathrm{KI}$ dan $\mathrm{KD}$, keakuratn materi dan materi pendukung pembelajaran. Untuk lebih spesifiknya akan membahas pada komponen yang terakhir yaitu materi pendukung pembelajaran, tujuannya untuk melihat berapa besar tingkat kelayakan materi pendukung pembelajaran yang menunjang dalam buku teks

Fungsi dari materi pendukung pembelajaran dalam buku teks untuk melengkapi ulasan materi seperti ketersajian soal, contoh, gambar, tajuk, tugas-tugas yang merangsang keterampilan dan lain sebagainya. Permasalahan yang kerap terjadi dalam indikator ini adalah ketidaksinkronan antara soal dan pembahasan, kurang disajikannya contoh, gambar maupun uraian yang dapat menarik minat belajar peserta didik. Hal ini harus dapat diantisipasi agar kegiatan belajar-mengajar tetap berjalan dengan baik.

\section{STUDI LITERATUR}

\subsection{Pengertian Buku Teks}

Buku teks merupakan buku panduan yang digunakan oleh peserta didik maupun guru dalam pelakasanaan pembelajaran. Buku teks yang digunakan merupakan buku yang bahasannya mudah dipahami, mengaitkan pengalaman sehari-hari peserta didik sehingga dapat lebih mudah dimengerti. Menurut Husnita dan Zulva (dalam jurnal Pelangi, hlm. 150) "Buku Teks atau buku pelajaran merupakan buku pegangan yang digunakan oleh guru dalam mengajar, selain itu buku teks juga digunakan oleh siswa sebagai penunjang kegiatan pembelajaran baik di sekolah maupun di luar sekolah.”
Selain itu menurut Tarigan dan Tarigan (1986, hlm. 13) Buku teks adalah buku pelajaran dalam bidang tertentu, yang merupakan buku standar, yang disusun oleh para pakar. Dalam hal itu untuk maksud dan tujuan instruksional, yang diperlengkapi dengan sarana- sarana pengajaran yang serasi dan mudah dipahami oleh pemaikainya di sekolah- sekolah maupun perguruan tinggi sehingga dapat menunjang sesuatu program pengajaran."

Jadi dapat disimpulkan bahwa buku teks merupakan buku panduan yang digunakan baik untuk peserta didik maupun guru dalam proses pembelajaran. Dengan adanya buku teks mempermudah pengajaran dimana melibatkan semua peserta didik didalam kelas. Peserta didik juga lebih mudah dalam memahami dan menangkap materi yang dijelaskan karena materi yang disampaikan tertera dengan jelas didalam buku teks.

\subsection{Penilaian Kelayakan Isi Buku Teks}

Menurut Muslich (dalam Jurnal Kata 2014, hlm. 3) dalam kelayakan isi, ada tiga indikator yang harus diperhatikan, yaitu "kesesuaian uraian materi dengan standar kompetensi (SK) dan kompetensi Dasar (KD) yang terdapat dalam mata pelajaran yang bersangkutan, keakuratan materi dan materi pendukung pembelajaran". Dari ketiga indikator tersebut kita dapat menilai sejauh mana tingkat kelayakan isi materi dalam sebuah buku teks. Sehingga dapat mengetahui kekurangan dan kelebihan dari buku teks yang akan digunakan sebagai acuan dalam pembelajaran.

\subsection{Materi Pendukung Pembelajaran}

$\begin{array}{crcr}\begin{array}{c}\text { Terdapat } \\ \text { pendukung }\end{array} & 10 & \begin{array}{c}\text { indikator } \\ \text { pembelajaran }\end{array} & \begin{array}{r}\text { mengenai materi } \\ \text { diantaranya }\end{array}\end{array}$ "Kesesuaiannya dengan perkembangan ilmu dan teknologi, keterkinian fitur, contoh, dan rujukan, penalaran (reasoning), pemecahan masalah (problem solving), keterkaitan antar konsep, komunikasi, penerapan, kemenarikan materi, mendorong untuk mencari informasi lebih jauh, materi pengayaan." (Muslich, 2010, hlm. 295-297). Adapun penjelasannya sebagai berikut:

a) Kesesuaiannya dengan Perkembangan Ilmu dan Teknologi

Materi yang tersaji dalam buku teks mencakup contoh, latihan dan daftar pustaka harus sesuai dengan kondisi saat ini dan sesuai dengan perkembangan ilmu teknologi. Artinya materi yang 
tersaji disesuaikan dengan kebutuhan peserta didik dan guru.

b) Keterkinian Fitur, Contoh, dan Rujukan

Pada indikator ini tak terlepas dari materi yang digunakan, artinya fitur, contoh dan rujukan merupakan tambahan untuk menjelaskan materi yang tersaji. Tiga indikator yang digunakan menggambarkan fenomena saat ini. Rujukan yang baik dan layak digunakan adalah rujukan yang lima tahun terakhir untuk buku teks.

c) Penalaran (Reasoning)

Dengan adanya penalaran mengasah daya ingat dan tingkat pemahaman peserta didik mengenai materi yang sudah dipelajari. Tujuannnya adalah agar peserta didik mampu membuat kesimpulan dari materi yang sudah dijelaskan. Cara yang tepat untuk melatih penalaran siswa dibantu dengan uraian, contoh, tugas, pertanyaan atau soal latihan yang sesuai dengan materi yang tertera dalam buku teks.

d) Pemecahan Masalah (Problem Solving)

Buku teks yang berkualitas harus mampu menyajikan suatu permasalahan disertai dengan strategi dan latihan pemecahan masalah. Untuk melatih pemecahan masalah, sebelumnya peserta didik harus mampu memahami masalah yang terjadi, merancang strategi pemecahan masalah, menguji coba strategi, mencari solusi dan menafsirkan solusi yang diperoleh.

e) Keterkaitan Antara Konsep Keterkaitan antar konsep dibuktikan dengan uraian atau contoh yang tersaji didalam buku teks. Tujuannya untuk membantu peserta didik mengkontruksi pengetahuan yang baru dan utuh. Serta konsep ini berkaitan dengan mata pelajaran sosiologi.

f) Komunikasi (Writeand Talk) Materi yang tersaji dalam buku teks baiknya menghadirkan contoh latihan untuk mengemukakan gagasan peserta didik berkaitan dengan materi yang sudah dipelajari, baik secara tertulis maupun secara lisan.

g) Penerapan (Aplikasi)

Pengetahuan yang sudah disampaikan oleh guru hendaknya dapat bermanfaat dan diaplikasikan dalan kehidupan sehari-hari siswa. Acuannya berasal dari contoh atau soal yang berkaitan dengan konsep dalam kehidupan nyata.

h) Kemenarikan Materi

Untuk menarik minat belajar siswa hendaknya buku teks dapat menyajikan uraian, strategi gambar, foto, sketsa, cerita sejarah, contoh atau soal-soal yang menarik sehingga peserta didik memiliki motivasi untuk mempelajari lebih dalam.

i) Mendorong Untuk Mencari Informasi Lebih Dalam
Dalam point ini peserta didik dituntut untuk mampu menggali lebih dalam lagi materi yang dipelajari dengan mencari informasi dengan sumber yang berbeda.

j) Materi Pengayaan

Materi pengayaan merupakan materi yang menunjang atau materi yang memperkaya materi pokok. Tujuannya untuk mengetahui apakah materi yang sedang dipelajari memiliki tingkat keluasan yang dapat didukung oleh sudut pandang ilmu lain.

\section{METODE PENELITIAN}

Penelitian ini menggunakan pendekatan kualitatif dengan menggunakan metode deskripsi. Penelitian ini dilakukan di SMA Negeri 2, SMA Negeri 6 dan SMA Negeri 19. Informan dalam penelitian ini sebanyak 3 orang, yaitu guru kelas XI yang mengajar mata pelajaran sosiologi dan menggunakan buku teks esis. Pihak-pihak tersebut dianggap memiliki informasi yang diperlukan oleh peneliti untuk mengungkapkan dan menganalisis buku teks Esis yang pada umumnya dijadikan acuan dalam pembelajaran.

Pemilihan partisipan ini menggunakan purposive sampling, dan hasil penelitian diperoleh dengan teknik observasi, studi dokumentasi dan wawancara. Teknik analisis data yang digunakan adalah analisis konten, dimana peneliti membaca, memahami secara mendalam buku teks esis. Sejalan dengan pendapat Rustanto (2015, hlm. 4) "Analisis isi (content analysis) adalah penelitian yang bersifat pembahasan mendalam terhadap isu suatu informasi tertulis atau tercetak dalam media massa." Untuk melihat tingkat kelayakan isinya menggunakan teknik penskoran sebagai berikut:

Presentase Kelayakan $=($ Skor Jawaban $/$ Skor Maksimal) x 100\%.

\section{HASIL DAN PEMBAHASAN}

Dari hasil perhitungan keseluruhan mengenai komponen Materi Pendukung Pembelajaran didapatkan presentase sebesar $72,5 \%$ dan berada pada tingkat kelayakan yang layak. Hasil analisis peneliti mengenai indikator pertama yaitu kesesuaian dengan perkembangan IPTEK dalam materi ini kurang menekankan dibidang teknologi. Materi yang menyajikan indikator teknologi hanya terdapat pada materi permasalahan sosial pada sub materi pengertian permasalahan sosial, materi Perbedaan, Kesetaraan dan Harmoni Sosial pada sub materi diferensiasi profesi. Terakhir pada materi 
Integrasi dan Reintegrasi pada sub materi Reintegrasi

Keterkinian fitur contoh dan rujukan dalam materi ini merupakan hal yang kerap kita temukan dalam masyarakat pada saat ini dan bersifat dinamis hanya saja terdapat salah satu contoh dalam materi kelompok sosial yang menampilkan pola hubungan antar kelompok dengan menampilkan contoh yang berkaitan dengan persitiwa sejarah. Selebihnya telah menampilkan contoh yang sesuai dengan kondisi saat ini dan maksimal contoh 5 tahun terakhir.

Penalaran dalam aspek ini dikaitkan dengan soal dan latihan yang menunjang dalam buku teks. Dari hasil analisa peneliti bahwa soal yang disajikan sudah dapat membantu proses menalar peserta didik. Sebab didukung dari berbagai varian soal, terdapat soal uji Penguasaan Materi dan Evaluasi yang dikaji sesuai dengan pembahasan. Namun terdapat kekurangan bahwa ada beberapa pertanyaan yang tidak ada pembahasannya, hal ini terjadi ketidak sinkronan antara soal dan pembahasan yang serupa dengan hasil penelitian skripsi yang dilakukan oleh Sofiyatun (2015) menyebutkan bahwa beberapa kesalahan yang terdapat dalam beberapa bab terkait kesalahan soal, ketidak sinkronan antara materi yang telah dipaparkan dengan soal-soal yang disajikan. Selain untuk tingkat kerumitan belum disesuaikan dengan berdasarkan Taksonomi Bloom.

Pemecahan masalah, untuk mendukung aspek pemecahan masalah dalam buku teks ini ditunjang dengan tersedianya kolom studi kasus yang membahas mengenai suatu kasus yang pernah terjadi dan peserta didik ditugaskan untuk mengidentifikasi kasus tersebut berserta solusinya. dengan adanya aspek pemecahan masalah dapat membantu dan membentuk proses berpikir peserta didik untuk menemukan solusi dari suatu permasalahan. Sehingga ketika peserta didik dihadapkan pada suatu kondisi permasalahan, ia sudah memiliki dasar untuk mengambil suatu tindakan yang tepat.

Indikator kelima dalam aspek ini adalah keterkaitan antar konsep. Pada umumnya semua bab dalam materi ini sangat terkait satu sama lain, hampir semua bab memiliki keterkaitan yang erat sehingga membangun konstruksi pengetahuan dan pengalaman baru bagi peserta didik. Diawali dengan materi kelompok sosial yang saling terkait dengan materi permasalahan, konflik, diferensiasi dan stratifikasi. Penjabaran spesifiknya sudah dijelaskan pada pembahasan diatas. Namun keterkaitan ini tidak tersaji secara eksplisit.

Komunikasi, indikator komunikasi didukung dengan kolom aktivitas yang tersaji setelah pembahasan materi telah selesai dipelajari. Umumnya dalam kolom aktivitas peserta didik ditugaskan untuk mengindentifikasi suatu kejadian yang berkaitan dengan materi yang sedang dipelajari sesuai dengan kondisi dilingkungan tempat tinggalnya. Dengan begitu merangsang peserta didik untuk berpikir dan berdiskusi dengan teman kelompoknya yang menimbulkan komunikasi antar peserta didik. Adapun pengertian pemahaman menurut Usman (2002, hlm. 35) "sebagai domain kognitif hasil belajar". Artinya jika sudah dapat memahami materi dengan baik maka dapat berdiskusi suatu permasalahan dengan lancar.

Indikator ketujuh adalah penerapan, secara umum menurut hasil analisis peneliti, bahwa penerapan merupakan hasil dari pemahaman peserta didik untuk mengaplikasikan materi yang didapatkan didalam kelas dan terapkan dalam kehidupan sehari- hari. Dari hasil pemahaman materi yang baik maka peserta didik dapat mengaplikasikannya pada kehidupan sehari-hari sehingga bermanafaat terutama bagi dirinya. Bukti pengaplikasian tersebut sesuai dengan pendapat yang dilontarkan oleh Daryanto (dalam Zuchdi, 2007, hlm. 24) bahwa "kemampuan pemahaman didasarkan tingkat kepekaan dan derajat penyerapan materi”.

Selain itu menurut Budimansyah dan Siti (2012, hlm. 10) "peristiwa belajar yang sebenar- benarnya dapat disebut belajar, mestilah merupakan kegiatan yang benaar-benar aktif dan terfokus untuk menghasilkan sesuatu, dan hasilnya adalah sesuatu yang belum ada atau belum dimiliki oleh orang yang belajar itu". Ketika peserta didik sudah mampu memahami materi yang disampaikan oleh guru maka dapat dikatakan proses belajar karena belajar merupaka pemahaman dari tidak tahu menjadi tahu dari bisa menjadi bisa.

Jika dikaitkan dengan teori, maka pengaplikasian ini sesuai dengan teori perkembangan kognitif dari Piaget. Menurut Piaget (dalam Surya, 2004, hlm 37) "perkembangan kognitif merupakan suatu proses dimana tujuan individu melalui suatu rangkaian yang secara kualitatif berbeda dalam berpikir". Artinya untuk mampu menerapkan dan mengaplikasikan materi yang telah diajarkan berdasarkan jenjang usia dalam berpikir. Sebab tingkatan berpikir anak kecil dengan remaja atau orang dewasa memiliki tingkat perbedaan yang signifikan sehingga jika peserta didik sudah dapat memecahkan permasalahan yang berkaitan dengan materi hal tersebut merupakan rangkaian kualitatif dalam berpikir.

Point kedelapan adalah kemenarikan materi, yang terbagi kedalam satu indikator yaitu terdapat uraian, gambar, contoh dan tajuk yang dapat menarik minat. Namun untuk uraian materi secara keseluruhan sudah dipaparkan dengan lugas dan tertuju langsung pada inti materi, bahasa yang digunakan dalam menguraikan mudah dipahami. Untuk contoh dan gambar kuantitasnya sangat 
terbatas sehingga diatasi dengan mencari sumber lain atau mengaitkan dengan fenomena yang ada dan untuk tajuk secara keseluruhan belum terpenuhi dengan baik, alasannya tajuk yang dihadirkan hanya terdapat pada 1 atau 2 bab. Pendapat lain dalam peneliti secara keseluruhan buku teks Esis kurang full color sehingga terlihat monoton warnanya. Identik dengan warna orange dan putih. Dapat disimpulkan bahwa kemenarikan materi harus lebih ditunjang dengan contoh, gambar, tajuk dan warna yang menarik agar dapat menarik minat baca peserta didik.

Point ke sembilan, mendorong informasi lebih dalam. Materi yang telah dipaparkan, pada umumnya terdapat beberapa kekurangan sehingga perlu dilengkapi untuk menunjang kelengkapannya. Terakhir, Materi pengayaan. Secara keseluruhan dalam materi yang tersaji diperkaya dengan sudut pandang atau ilmu lain, umumnya materi ini diperkaya dengan ilmu ekonomi, hukum, politik, sosila, psikologi sosial, sejarah, dan sebagainya. Alasannya karena materi sosiologi merupakan ilmu yang berkaitan dengan masyarakat sehingga ditunjang dengan ilmu-ilmu lain untuk memberikan penjelasan secara rinci.

\section{KESIMPULAN}

Materi pendukung pembelajaran hasil presentase keseluruhannya sebesar $72,5 \%$ dengan status layak. Indikator kesesuaian dengan IPTEK, secara keseluruhan untuk pengetahuan sudah tersaji dengan baik sedangkan untuk aspek teknologi hanya terdapat pada materi permasalahan sosial, Bab 3 dan Bab 5 Keterkinian fitur contoh dan rujukan sudah disajikan sesuai dengan materi dan kondisi saat ini.

Penalaran, dikaitkan dengan soal dan latihan yang menunjang dalam buku teks, hanya terdapat catatan penting untuk indikator ini yaitu terdapat ketidak sinkronan antara materi dengan soal yang disajikan dan tingkat kerumitan soal disesuaikan dengan Taksonomi Bloom. Pemecahan masalah didukung dengan kolom studi kasus di setiap pembahasannya. Untuk keterkaitan antar konsep materi yang tersaji saling keterkaitan satu sama lain. Untuk komunikasi didukung dengan kolom aktivitas yang dapat membangun komunikasi peserta didik dengan berdiskusi. Indikator penerapan, dibuktikan dengan pengaplikasian materi dalam kehidupan sehari-hari peserta didik. Kemenarikan materi, secara keselurhan ini kurang menarik karena kurang disajikan contoh dan gambar yang memadai. Aspek untuk mendorong informasi lebih dalam ditunjang dengan informasi yang kurang mendalam seperti yang sudah disebutkan dalam simpulan nomor satu. Dan untuk materi pengayaan, materi yang terdapat dalam buku teks Esis sudah diperkaya dengan sudut pandang ilmu lain.

\section{REFERENSI}

Budimansyah, Dasim dan Siti Komariah. (2012). Belajar dan Pembelajaran Sosiologi. Bandung: Prodi Pendidikan Sosiologi FPIPS UPI

Firdaus, Aziz dan Siti Samhati. (2014). Analisis Kelayakan Isi Buku Teks Bahasa Indonesia Terbitan Erlangga Kelas Vii Smp/Mts. Jurnal Kata (Bahasa, Sastra dan Pembelajarannya), 2 (2), hlm. $2-14$

Husnita, Liza dan Zulfa. (2015). Analisis kelengkapan materi buku teks sejarah kelas XI yang dipakai di sekolah-sekolah SMA di Kota Padang (Buku Erlangga, Platinum, Bumi Aksara dan Yudistira). Jurnal Pelangi, 7 (2), hlm 148165

Muslich, Masnur. (2010) . Text Book Writing. Jogjakarta: Ar-ruzz

Nasution, M. A.(2008). Kurikulum dan Pengajaran. Jakarta: PT Bumi Aksara

Rustanto, Bambang. (2015). Penelitian Kualitatif Pekerjaan Sosial. Bandung: PT Remaja Rosdakarya Offeset

Safdar, dkk. (2011). An analysis of Biology Textbook for 9th Class Published By NWFP textbiik Board Peshawar, Pakistan. International Journal of Academy Research, 3(2), hlm.13

Shofiyatun Nisyak. (2015). Analisis Kelaykan Isi Dan Bahasa Buku Bajar Pendidikan Agama Islam Dan Budi Pekerti Sekolah Menengah Pertama (SMP) Kelas Tujuh (VII) Penerbit Kementrian Pendidikan dan Kebudayaan. Skripsi. [Online] Tersedia di docplayer.info Diakses [22 Febuari 2017].

Surya, Mohamad, (2004). Psikologi dan Pembelajaran. Bandung: Pustaka Bani Quraisy

Tarigan, H, G \& Tarigan, D. (2009). Telaah Buku Teks Bahasa Indonesia. Bandung: Angkasa

Usman, Moh. Uzer. (2002). Menjadi Guru Profesional (Cet. XIV). Ed. II. Bandung: PT Remaja Rosdakarya

Zuchdi, Darmiyati. (2007). Strategi Meningkatkan Kemampuan Membaca. Yogyakarta: UNY Press 